\title{
Information Content of Earnings and Operating Cash Flows: Evidence from the Tehran Stock Exchange
}

\author{
Abbasali Pouraghajan ${ }^{1}$, Milad Emamgholipour ${ }^{2}$, Faramarz Niazi ${ }^{3} \&$ Ali Samakosh ${ }^{4}$ \\ ${ }^{1}$ Department of Accounting, Qaemshahr Branch, Islamic Azad University, Qaemshahr, Iran \\ ${ }^{2}$ Department of Accounting, Babol Branch, Islamic Azad University, Babol, Iran \\ ${ }^{3}$ Faculty of Economics and Administrative Sciences, Institute of Higher Education, Allameh Mohaddes Noori, Noor, \\ Iran \\ ${ }^{4}$ Department of Accounting, Mazandaran Science and Research Branch, Islamic Azad University, Sari, Iran \\ Correspondence: Abbasali Pouraghajan, Assistant Professor and member of the faculty, Department of Accounting, \\ Qaemshahr Branch, Islamic Azad University, Qaemshahr, Iran. Tel: 98-911-112-7182. E-mail: \\ abbas_acc46@yahoo.com
}
Received: April 16, 2012
Accepted: May 14, 2012
Published: July 1, 2012
doi:10.5539/ijef.v4n7p41
URL: http://dx.doi.org/10.5539/ijef.v4n7p41

\begin{abstract}
The main objective of this study is to evaluate the relative and incremental information content of earnings and operating cash flows in the companies listed in Tehran Stock Exchange. Moreover, the present study investigates the loss effect on the information content of earnings and operating cash flows. For this purpose, we investigate and analyze a sample of 475 firm-years from the companies listed in Tehran Stock Exchange during the years 2006-2010.The results indicate that, the earnings have more information content than operating cash flows in explaining stock returns. In addition, earnings model is preferable in explaining stock returns than operating cash flows model. Also, results show that earnings have positive effect and loss has negative effect on earnings information content and operating cash flows.
\end{abstract}

Keywords: relative information content, incremental information content, earnings, operating cash flow

\section{Introduction}

The purpose of accounting is to provide financial information relating to the business units for users in order to assist decision-making process, while the purpose of accounting research is to evaluate the usefulness of accounting information for investors and other users. Financial statements are very important sources of information that investors need while making investment-related decisions (Hadi, 2006).

Among accounting information, accounting earnings are considered as the most important source of information for evaluating the profitability and future cash flows. In the meantime, operating cash flows are not less important. According to the accounting standard No 2 of Iran (related to the Cash Flow Statements), the amount of cash flows from operating activities is one of the main indicators of evaluating the issue that to what extent business unit operations result in adequate cash flows in order for the reimbursement of loans, maintenance of operating power of business unit, and payment of stock returns and provides implementation of new investments without resorting to financing resources out of business unit. Providing information about elaboration of operating cash flow, along with other information, will be useful for predicting future cash flows (Iran's Accounting Standards, No. 2, 2007). Therefore, the ultimate purpose of accounting is to provide useful information for users in economic decisions.

The usefulness of information is one of the most important indicators of accounting systems projection and indicates that with regard to the different groups of accounting information users and their diverse information needs and due to lack of access to all the information needed for this groups, the above-mentioned index enables us to emphasize the types of information in accounting system that has been proved their effectiveness in providing decision makers' purposes (Tehrani and Faniasl, 2007). Given this, we can use the index "usefulness in forecasting" as a criterion to evaluate accounting information which has been used from this index in the formulation of accounting theory. According to this index, among different methods of accounting, a method that has the highest predictive power and relative advantage over other methods in a subject or a particular event may be selected as the best method. Thus accounting information includes the numbers that have information content and help users in forecasting economic events. 
Information content of accounting items are related to forecasting some factors such as returns and dividends. Purpose of information content of an accounting criteria is the amount of use and its usefulness in decision-making process of capital market participants. In other words, information content of accounting item refers to the usefulness of that item in decision making process. Overall, the information content test is discussed in two formats, relative and incremental information contents. The studies on incremental information content of accounting investigate the issue that whether one or more accounting criteria add something more than other variables to them or not. But the topic of relative information content is when the researcher wants to find between two or more criteria of accounting which has information content more than other variables in order to achieve a ranking of the criteria. In fact, the relative information content indicates that whether the information content of $X$ alone is larger, smaller or equal to information content of $\mathrm{Y}$ alone. But the incremental information content indicates that whether the information content of $\mathrm{X}$ and $\mathrm{Y}$ together are larger than a variable alone or not (Biddle et al., 1995).

With regard to the mentioned material and also the fact that evaluating the stock returns of different companies are the most important issues for investors in capital markets, this research seeks to answer three following questions, which in fact are the objectives of research as well, and it can provide a measure to predict stock returns of different companies for investors and help them with confidence in making decisions about selection or purchase of companies' stock.

1) Do earnings have more relative information content than operating cash flows in explaining stock returns or vice versa?

2) Does loss affect the information content of earnings or the information content of operating cash flows?

3) Do earnings have more incremental information content than operating cash flows or vice versa?

In other words, the present study investigates the relative and incremental information content of earnings and operating cash flows in explaining stock returns for companies listed in Tehran Stock Exchange and are investigated by using the relationship between earnings and operating cash flows with stock returns. The study also uses the adjusted R2 values, Akaike information criteria and Vuong's test to select the best model to explain stock returns. The background research and analysis methods and research findings are presented in the following.

\section{Literature Review}

Accounting earnings and operating cash flows were the subject of conducted research by some researchers. Following investigation and study, the research results related to the topic of this research are presented as follows.

Wilson (1986) in his study refers to investigation of relative information content of accruals and operating cash flows, but examined incremental information content of accruals and operating cash flows. He investigated 332 firm-years during the period of 1981-1982 in his study. The research results indicate that cash flows and accruals components of earnings have incremental information content than earnings itself, and also accruals components of earnings have more incremental information content than cash flows. In addition, obtained evidence shows that incurrent accruals have not more incremental information content than working capital from operations before earnings items.

Bowen et al.(1987) in their study Surveyed incremental information content of accruals versus cash flows. They use earnings and capital variables for accruals in working from operations and from cash flows variables from operations and cash flows result from investing activities for cash flows in the study. Their research results which covered a 10 -year-old period and used econometrics models and also multivariable regressions and cross-sectional regression indicate that (1) Information related to cash flows has incremental information content than earnings; (2) information related to cash flows has incremental information content than simultaneously information of earnings and working capital from operations; and (3) Information related to accruals (earnings and working capital from operations) simultaneously and separately, has incremental information content than cash flows.

Ali (1994) in his study investigated the incremental information content of earnings, working capital from operations and cash flows of American companies between the years 1974-1988 with 8820 firm-years samples. He used linear and nonlinear models to test hypotheses in his study. The obtained results of the linear model test confirmed incremental information content of earnings than working capital from operations and cash flows, but the obtained results of nonlinear model test confirmed incremental information content of working capital from operations than earnings and cash flows. But concerning incremental information content of cash from operations than others were observed two modes. In the first mode, companies that have low changes in cash from operations were observed incremental information content than the others and in the second mode, companies that have a lot of changes in cash from operations, were not observed incremental information content than the others.

Cheng et al. (1996)Surveyed earnings permanence and incremental information content of cash flows from operations in the companies listed in New York Stock Exchange during the years 1988-1992.In this study, they selected 5120 
firm-years observations as samples. Obtained results indicate that with decline of constancy or permanence of earnings, incremental information content of earnings decreased and incremental information content of cash flows from operations increased.

Charitou et al. (2000) in their study examined value relevance of earnings and cash flows in Japanese companies. In this research, they investigated 6662 firm-years observations among the companies listed in Japan Stock Exchange during the years 1984-1993. In this research, they used from stock returns as dependent variable and earnings and operating cash flows as independent variable. The research results show evidence that (1) cash flows have more information content than earnings in explaining stock returns and (2) cash flows play more important role in stock returns than earnings and have more significance when earnings have not permanency. And also their study show that Japanese investors use earnings and cash flows in selection of stock basket than American investors.

Haw et al. (2001) investigated the information content of earnings, operating cash flows and accruals in the companies listed in China's capital market during the years 1995-1998. In this study, they selected 1516 firm-years as samples. Obtained results indicate that earnings have more information content than operating cash flows. Also in this study, the incremental information content of discretionary accruals versus nondiscretionary accruals was confirmed.

Habib (2008) in his study surveyed the role of accruals and cash flows in explaining stock returns during the period 1994-2004 for New Zealand companies. In this study, he selected 705 firm-years observations as samples. The research results indicate that (1) earnings have more explanatory power than cash flows, and (2) both earnings and cash flows have incremental information content for stock returns.

Daraghma (2010) in his study investigated relative and incremental information content of earnings and operating cash flows for the companies listed in Palestinian Stock Exchange during the years 2004-2008 in 23 companies as samples. In this research, he used stock returns as dependent variable and the earnings and operating cash flows as independent variables. In the present study, the adjusted $\mathrm{R}^{2}$ values, Akaike information criteria and Vuong's test for selecting the best model to explain stock returns were also used. The results indicate that (1) earnings have more relative information content than the operating cash flows, (2) incremental information content of earnings is more than operating cash flows, (3) earnings have positive effect on value relevance and operating cash flows but loss has negative effect on value relevance and operating cash flows, and (4) earnings model is preferable than operating cash flows in explaining stock returns.

\section{Research Hypotheses and Objectives}

With regard to the mentioned themes, this study pursues the following objectives:

1) To investigate relative information content of earnings and operating cash flows in the companies listed in Tehran Stock Exchange.

2) To test loss effect on the information content of earnings and operating cash flows.

3) To test incremental information content of earnings and operating cash flows.

Given the above objectives, to investigate the information content of earnings and operating cash flows of companies, the following hypotheses are designed:

$\mathbf{H}_{1}$ : Earnings have more relative information content than operating cash flows in relation to explaining stock returns.

$\mathbf{H}_{2}$ : Loss affects the information content of earnings.

$\mathbf{H}_{3}$ : Loss affects the information content of operating cash flows.

$\mathbf{H}_{4}$ : Earnings have more incremental information content than operating cash flows in relation to explaining stock returns.

\section{Research Design}

\subsection{Statistical Society and Sample}

Statistical society of this study includes all companies listed in Tehran Stock Exchange. To determine the sample size, first it must be examined that to what extent company information is available. After investigating into the selection of sample in the best situations for a 5-year-old period (2006-2010), 95 companies were selected as sample and for data collection. To select the desired sample, the following criteria are considered:

1) The end of financial period of companies lead up to December 31 of each year.

2) The operations are not interrupted during the study period.

3) It should not be investment and financing and leasing companies. 
4) They were accepted before2006 in Tehran Stock Exchange.

5) Financial period have not changed in the course of study.

6) The required data are available.

The desired sample is selected by elimination (purposive) method. Thus selected sample includes all companies which were the member of population and had above circumstances.

\subsection{The Data Collection Method}

In this study, we used documents analysis method to collect data. Therefore, the needed data about member companies of sample in study during the 2006-2010 have been collected by the site of Tehran Stock Exchange (Note 1) and CDs of financial data in companies listed in Tehran Stock Exchange.

\subsection{Research Variables and Their Measurement Method}

\subsubsection{The Dependent Variable}

Stock returns: at present, usually most important measure for performance evaluation of institutions is stock returns rate. This measure alone has information content for investors and is used for performance evaluation. When this measure is reduced, it is a warning for company and does not show good performance of the company. Return in investors' process is a driving force that will motivate and is considered a reward for investors. Return is the total income that an investor will gain during the period of investing. Return includes changes in the real capital (stock price) and receivable cash dividend. In the present study, the following equation is used to calculate the stock returns:

$$
R_{i t}=\frac{P_{i t}-P_{i(t-1)}+D_{i t}}{P_{i(t-1)}}
$$

Where:

$R_{i t}$ : The stock return of company $\mathrm{i}$ in period $\mathrm{t}$,

$P_{i t}$ : The stock market prices of company i at the end of period $\mathrm{t}$,

$P_{i(t-1)}$ : The stock market prices of company $\mathrm{i}$ at the beginning of period $\mathrm{t}$,

$D_{i t}$ : Cash dividends belong to per share of company $\mathrm{i}$ in period $\mathrm{t}$.

In this research, the stock returns of studied company are calculated according to above-mentioned equation for 12 months from beginning to the end of year $t$.

\subsubsection{The Independent Variables}

Earnings: A net operating earnings (loss) has been selected as representative of accounting earnings. The number of net operating earnings (loss) is extracted from audited annual financial statements of the studied companies. To calculate net operating earnings (loss) in different companies, this study used the net operating earnings to total assets ratio.

Operating cash flows: Operating cash flows refer to those inputs and output cash flows that result from operational activities of the company. Also those cash flows that naturally cannot be connected directly to the other classes of cash flows in cash flow statement are considered as cash from operations. The number of operating cash flows is extracted from audited annual financial statements of the studied companies. To calculate operating cash flows in different companies, the present study used the operating cash flows to total assets ratio.

\subsection{CorrelatedModels with Hypotheses Testing}

In the present study, to test hypotheses, three models are used to investigate the information content of earnings and operating cash flows:

In these models:

$$
\begin{gathered}
R_{i t}=\beta_{0}+\beta_{1} E_{i t} \\
R_{i t}=\theta_{0}+\theta_{1} O C F_{i t} \\
R_{i t}=\gamma_{0}+\gamma_{1} E_{i t}+\gamma_{2} O C F_{i t}
\end{gathered}
$$

$R_{i t}$ : The stock returns of company $\mathrm{i}$ in period $\mathrm{t}$,

$E_{i t}$ : The earnings of company $\mathrm{i}$ in period $\mathrm{t}$,

$O C F_{i t}$ : Cash flows from operations of company $\mathrm{i}$ in period $\mathrm{t}$. 
$\beta_{0}, \theta_{0}$ and $\gamma_{0}$ are constant coefficients (intercept) and $\beta_{1}, \theta_{1}, \gamma_{1}$ and $\gamma_{2}$ are variables coefficients. That $\mathrm{B}_{1}$ and $\gamma_{1}$ are earnings response coefficients (ERC), $\theta_{1}$ and $\gamma_{2}$ are operating cash flow response coefficient (OCFRC). Therefore, earnings or operating cash flows have information content when the reaction coefficient (i.e. ERC and OCFRC) be statistically significant. Also we classify companies in two subsidiary samples or two portfolios to test the effect of loss on information content of earnings (E) and operating cash flows (OCF).Those two portfolios are earnings portfolio (positive earnings) and loss portfolio (negative earnings).

\subsection{Data Analysis Methods and Hypotheses Testing}

To analyze data and test hypotheses, linear regression analysis and Pearson and Spearman correlation are used; i.e. first we calculated needed data for doing test and then performed regression tests for investigating relative and incremental information content of earnings and operating cash flows of companies. Also we used SPSS.18 and EXCEL software for data processing and statistical tests. To test the statistical hypotheses, first we investigated the accuracy of the obtained regression model assumptions and then we use adjusted $\mathrm{R}^{2}$ values, Akaike information criteria (AIC) and Vuong's test to select the best model to explain stock returns. Based on Akaike information criteria (AIC), a model that has the lowest AIC will select the best model to explain stock returns (Akaike, 1974).

Vuong in 1989 presented a statistical test to determine which of the two models explains better the dependent variable (Foroghi and Mazaheri, 2009). In the present study, to determine which of these competing models can better explain stock returns, Z Vuong's statistic has been used. Z Vuong's statistic is calculated as the following equation:

$$
Z_{\text {Vuong }}=\frac{\left[\log \left(\sigma_{w}^{2}\right)-\log \left(\sigma_{x}^{2}\right)\right]}{\left[n^{1 / 2} \sum_{l}^{n}\left(\frac{e_{w, i}^{2}}{\sigma_{w}^{2}}-\frac{e_{x, i}^{2}}{\sigma_{x}^{2}}\right)\right]^{2}}
$$

$\sigma_{\mathrm{x}}^{2}$ and $\sigma_{\mathrm{w}}{ }^{2}$ in the above equation are calculated as follows:

$$
\begin{aligned}
& \left(\sigma_{x}^{2}\right)=\sigma_{Y}^{2}\left(1-R_{x}^{2}\right) \\
& \left(\sigma_{w}^{2}\right)=\sigma_{Y}^{2}\left(1-R_{w}^{2}\right)
\end{aligned}
$$

In this equation: $\sigma_{\mathrm{x}}{ }^{2}$ : residual variance for the first model, $\sigma_{\mathrm{w}}{ }^{2}$ : residual variance for the second model, $\sigma_{\mathrm{y}}{ }^{2}$ : variance of the dependent variable, $\mathrm{n}$ : number of observations, $\mathrm{R}_{\mathrm{x}}{ }^{2}$ : multiple correlation coefficient of the first model $\mathrm{R}_{\mathrm{w}}{ }^{2}$ : multiple correlation coefficient of the second model (Dechow et al., 1998). In Vuong's test, from the Model 1 and 2, a model that can explain better the stock returns may be selected. So in the above-mentioned equation, the $\mathrm{X}$ is accounting earnings (model 1) and $\mathrm{W}$ is operating cash flow (model 2) and $\mathrm{Y}$ is the stock return (dependent variable). With regard to what has been said above, the statistical hypotheses are proposed for Vuong's test (Z Vuong) as follows:

$\mathrm{H}_{0}$ : the two models are equal to explain stock returns $(\mathrm{Z}=0)$.

$\mathrm{H}_{1}$ : One of the two models further explains stock returns $(\mathrm{Z} \neq 0)$.

According to the hypotheses of this test, if Z Vuong's statistic:

A) is positive; the first model is superior to the second model.

B) is negative; the second model is superior to the first model.

C) is zero, none of the two models are better than each other (Dechow, 1994).

Considering these, models and criteria to test used research hypotheses are as follows: (1) to test the relative information content of earnings and operating cash flows in explaining stock returns (hypothesis 1) used models 1 and 2 , and also the values of three criteria, adjusted $\mathrm{R}^{2}$, Akaike information criteria (AIC) and Vuong's test (2) to examine the effect of loss on the information content of earnings and operating cash flow (hypothesis 2 and 3) have used models 1 and 2, and adjusted $\mathrm{R}^{2}$ values. And finally, (3) to test the Incremental information content of earnings and operating cash flows in explaining stock returns (Hypothesis 4) used the Model 3 with Model 1 and 2, and adjusted $\mathrm{R}^{2}$ values and Akaike information criteria (AIC).

\section{Empirical Results}

\subsection{Descriptive Statistics}

Descriptive statistics of dependent and independent variables to test the hypotheses are shown in Table 1 in which the numbers of observations equal 475 firm-years during the years 2006-2010. In order to reduce data heteroscedasticity, all independent variables are shrunk by total assets of studied companies. As can be seen in Table 1, earnings have the 
lowest standard deviation. Also the highest mean is related to stock returns and the highest median is related to the earnings. These statistics show that sample has necessary diversity to generalize the results to the community.

Table 1. Descriptive Statistics Data

\begin{tabular}{lccccc}
\hline \multicolumn{1}{c}{ statistics / variable } & Mean & Median & Maximum & Minimum & standard deviation \\
\hline $\mathbf{R}$ & & & & & \\
$\mathbf{E}$ & 0.206 & 0.048 & 7.763 & -0.972 & 0.878 \\
$\mathbf{O C F}$ & 0.118 & 0.106 & 0.610 & -0.180 & 0.113 \\
\hline
\end{tabular}

R: stock returns, E: earnings per share, OCF: operating cash flows

\subsection{Correlation Analysis}

Pearson correlation coefficients (parametric test) and Spearman correlation coefficients (nonparametric test) of dependent and independent variables are shown in Table 2. Calculated coefficients according to both methods are similar. Part A shows that there is a significant positive correlation between earnings and stock returns at $1 \%$ level with a coefficient of $39.8 \%$. Also this section indicates a significant positive correlation between OCF and stock returns at $1 \%$ level with a coefficient of $25.9 \%$. This shows significant positive correlation between two independent variables of earnings and OCF at $1 \%$ level with a coefficient of $46.8 \%$. In addition, Part B shows Spearman correlation coefficients that supports the Pearson correlation test (Part A).

Table 2. Correlation matrix (Pearson and Spearman correlation coefficients)

\begin{tabular}{|c|c|c|c|}
\hline \multicolumn{4}{|c|}{ Part A: Pearson correlation coefficients } \\
\hline Variable & $\mathbf{R}$ & $\mathbf{E}$ & OCF \\
\hline $\mathbf{R}$ & 1 & & \\
\hline $\mathbf{E}$ & $0.398 * *$ & 1 & \\
\hline OCF & $0.259 * *$ & $0.468^{* *}$ & 1 \\
\hline \multicolumn{4}{|c|}{ Part B: Spearman correlation coefficients } \\
\hline Variable & $\mathbf{R}$ & $\mathbf{E}$ & OCF \\
\hline $\mathbf{R}$ & 1 & & \\
\hline $\mathbf{E}$ & $0.506^{* *}$ & 1 & \\
\hline OCF & $0.315^{* *}$ & $0.481^{* *}$ & 1 \\
\hline
\end{tabular}

** Correlation is significant at $1 \%$ level.

\subsection{Regression Analysis}

\subsubsection{Relative Information Content of Earnings and Operating Cash Flows Test}

The first hypothesis of research indicated that earnings have more relative information content than operating cash flows in relation of explaining stock returns. To test this hypothesis, the simple regression is used to estimate the parameters model 1 and 2 . As was mentioned previously, model 1 is used to test the value relationship of earnings and model 2 is used to test the value relationship of operating cash flows.

Table 3 shows the results from simple regression to test the information content of earnings. The only independent variable in this table is earnings. $\mathrm{R}^{2}$ for the total sample is $15.8 \%$ and adjusted $\mathrm{R}^{2}$ for the total sample is $15.6 \%$. Earnings response coefficient (ERC) is 3.103 and statistically has a significant positive relationship at $1 \%$ level. The $\mathrm{F}$ statistic for the total sample and for each year is also significant. Annual regression results also provide similar pattern, but coefficients changed during different years and in all investigated years, ERS has a significant positive relationship at $1 \%$ level. But the power of explaining earnings in 1385 is more than other years. Therefore, the results indicate that earnings have information content. 
Table 3. Results of testing the value relationship of earnings $-R_{i t}=\beta_{0}+\beta_{1} E_{i t}$

\begin{tabular}{lcccccc}
\hline Year & Constant $\left(\boldsymbol{\beta}_{\mathbf{0}}\right)$ & $\begin{array}{c}\text { Earnings Response } \\
\text { Coefficient }\left(\boldsymbol{\beta}_{\mathbf{1}}\right)\end{array}$ & F-Value & $\mathbf{R}^{2}$ & ${\text { Adjusted } \mathbf{R}^{2}}^{\text {AIC }}$ \\
\hline \multirow{2}{*}{$\mathbf{2 0 0 6}$} & $-0.279^{*}$ & $3.634^{* *}$ & $34.007^{* *}$ & 0.291 & 0.282 & -1.540 \\
& -2.180 & 5.832 & & & & \\
\hline \multirow{2}{*}{$\mathbf{2 0 0 7}$} & $-0.199^{* *}$ & $1.669^{* *}$ & $17.384^{* *}$ & 0.180 & 0.170 & -1.180 \\
& -3.083 & 4.169 & & & & \\
\hline \multirow{2}{*}{$\mathbf{2 0 0 8}$} & $-0.234^{* *}$ & $2.031^{* *}$ & $15.842^{*}$ & 0.162 & 0.152 & -4.060 \\
& -3.334 & 3.980 & & & & \\
\hline \multirow{2}{*}{$\mathbf{2 0 0 9}$} & 0.342 & $2.200^{* *}$ & $6.958^{* *}$ & 0.082 & 0.070 & -0.616 \\
& 1.808 & 2.638 & & & & -0.244 \\
\multirow{2}{*}{$\mathbf{2 0 1 0}$} & 0.077 & $2.559^{* *}$ & $30.476^{* *}$ & 0.292 & 0.282 & \\
\hline \multirow{2}{*}{ Polled } & -1.207 & 5.521 & & & & -1.243 \\
& $-0.160^{* *}$ & $3.103^{* *}$ & $76.039^{* *}$ & 0.158 & 0.156 & \\
\hline
\end{tabular}

** Correlation is significant at $1 \%$ level, * correlation is significant at $5 \%$ level.

Table 4 shows the results from testing operating cash flows model. The only independent variable in this table is operating cash flows. $\mathrm{R}^{2}$ for the total sample is $6.7 \%$ and adjusted $\mathrm{R}^{2}$ for the total sample is $6.5 \%$.Operating cash flows response coefficient (OCFRC) is 1.621 and statistically has a significant positive relationship at $1 \%$ level. Also the $\mathrm{F}$ statistic for the total sample and for each year (except in 2008) is significant. Annual regression results are positive and in all studied years (except in 2008) are significant at $1 \%$ level and in 2008; OCFRC is not significant at conventional levels. The explanatory power of OCF in 2006 is located at the highest level. Thus, the results show that operating cash flows have also information content. Overall, with regard to the results, the regression of earnings has the higher explanatory power and coefficients than regression of operating cash flows. Therefore, the results indicate that the information content of earnings is more than OCF.

Table 4. Results of testing the value relationship of operating cash flows $-\mathrm{R}_{\mathrm{it}}=\theta_{0}+\theta_{1} \mathrm{OCF}_{\mathrm{it}}$

\begin{tabular}{|c|c|c|c|c|c|c|}
\hline Year & Constant $\left(\theta_{0}\right)$ & $\begin{array}{l}\text { OCF Response } \\
\text { Coefficient }\left(\theta_{1}\right)\end{array}$ & F-Value & $\mathbf{R}^{2}$ & Adjusted $\mathbf{R}^{2}$ & AIC \\
\hline \multirow{2}{*}{2006} & 0.118 & $2.731 * *$ & $11.571^{* *}$ & 0.122 & 0.112 & -2.540 \\
\hline & 0.708 & 3.402 & & & & \\
\hline \multirow{2}{*}{2007} & -0.084 & $0.810^{* *}$ & $7.261^{* *}$ & 0.084 & 0.073 & -0.067 \\
\hline & -1.516 & 2.695 & & & & \\
\hline \multirow{2}{*}{2008} & -0.037 & 0.108 & 0.068 & 0.001 & -0.011 & -2.581 \\
\hline & -0.515 & 0.260 & & & & \\
\hline \multirow{2}{*}{2009} & 0.342 & $2.200^{* *}$ & $6.958^{* *}$ & 0.082 & 0.070 & -0.768 \\
\hline & 1.808 & 2.638 & & & & \\
\hline \multirow{2}{*}{2010} & 0.029 & $1.507^{* *}$ & $9.914^{* *}$ & 0.118 & 0.106 & -1.787 \\
\hline & 0.437 & 3.149 & & & & \\
\hline \multirow{2}{*}{ Polled } & 0.010 & $1.621^{* *}$ & $28.980 * *$ & 0.067 & 0.065 & -0.297 \\
\hline & 0.186 & 5.383 & & & & \\
\hline
\end{tabular}

**Correlation is significant at $1 \%$ level.

In tables 3 and 4 the results of Akaike information criteria (AIC) test are shown, where the AIC value of the earnings model (model 1) is less than the AIC value of the operating cash flows model (model 2). As mentioned earlier, the model that has the lowest AIC are selected the best model to explain stock returns (Akaike, 1974). Therefore the earnings model is preferable than OCF model to explain stock returns. Table 5 shows the results of $Z$ Vuong's statistic using the total sample data of five years studied companies. Where, Z Vuong's statisticis calculated according to the 
Vuong's test model which already explained. Results from Table 5 shows that $Z$ Vuong's statistic is negative $\left(Z_{\text {vuong }}>0\right)$ and is equal to -3798.52. Based on Dechow, Lys and Sabino research (1998) If Z Vuong's statistic is smaller than zero (negative), earnings is preferable to OCF in explaining stock returns. Thus, accounting earnings in explaining stock returns is preferable to OCF.

Table 5. Results of Z Vuong's test for comparing earnings and operating cash flows models Z Vuong's statistic

\begin{tabular}{|c|c|}
\hline$Z_{\text {vuong }}=\frac{\left[\log \left(\sigma_{\mathrm{e}}^{2}\right)-\log \left(\sigma_{\text {ocf }}^{2}\right)\right]}{\left[\mathrm{n}^{1 / 2} \sum_{1}^{\mathrm{n}}\left(\frac{\mathrm{e}_{\mathrm{e}, \mathrm{i}}^{2}}{\sigma_{\mathrm{e}}^{2}}-\frac{\mathrm{e}_{\mathrm{ocf}, \mathrm{i}}^{2}}{\sigma_{\mathrm{ocf}}^{2}}\right)\right]^{2}}$ & \\
\hline \multicolumn{2}{|l|}{ The measure } \\
\hline Residual variance for earnings model $\sigma_{\mathrm{e}}^{2}$ & 0.65002 \\
\hline Residual variance for OCF model $\sigma_{\text {ocf }}^{2}$ & 0.72028 \\
\hline Natural logarithm for the variance of residual of earnings model $\log \left(\sigma_{\mathrm{e}}^{2}\right)$ & -0.18707 \\
\hline Natural logarithm for the variance of residual of OCF model $\log \left(\sigma_{\text {ocf }}^{2}\right)$ & -0.14250 \\
\hline$\sum_{1}^{\mathrm{n}}\left(\frac{\mathrm{e}_{\mathrm{e}, \mathrm{i}}^{2}}{\sigma_{\mathrm{e}}^{2}}-\frac{\mathrm{e}_{\mathrm{ocf}, \mathrm{i}}^{2}}{\sigma_{\mathrm{ocf}}^{2}}\right)$ & 0.00017 \\
\hline$\left[\mathrm{n}^{1 / 2} \sum_{1}^{\mathrm{n}}\left(\frac{\mathrm{e}_{\mathrm{e}, \mathrm{i}}^{2}}{\sigma_{\mathrm{e}}^{2}}-\frac{\mathrm{e}_{\mathrm{ocf}, \mathrm{i}}^{2}}{\sigma_{\mathrm{ocf}}^{2}}\right)\right]^{2}$ & 0.003425 \\
\hline Z Vuong's statistic & -3798.52 \\
\hline
\end{tabular}

Based on Dechow, Lys and Sabino research (1998) decision making rules are: 1- If Z Vuong's statistic is equal to zero, E and OCF in explaining stock returns are not preferable to each other. 2- If Z Vuong's statistic is greater than zero (positive), OCF in explaining stock returns is preferable to E. 3- If Z Vuong's statistic is smaller than zero (negative), E in explaining stock returns is preferable to OCF.

Values obtained from Adjusted $\mathrm{R}^{2}$, information Akaike information criteria (AIC) and Vuong's test, all show the relative information content of earnings into the OCF. So we can conclude that the first hypothesis will be confirmed indicating the relative information content of earnings is preferable to operating cash flows in explaining stock returns. Results are consistent with Daraghma's research results (2010).

\subsubsection{Loss Affects Test on the Information Content of Earnings and Operating Cash Flows}

In table 6, we have summarized the results from cross-sectional and collective regression about loss effect on the information content of earnings and operating cash flows. This section of article has been done for the first time for Iranian companies. To investigate loss effect on the information content and OCF, samples is divided in to two portfolios, portfolio of positive earnings (earnings) and the portfolio of negative earnings (loss).

Part A shows the simple regression results of earnings (Model 1) to test loss effect on the information content of earnings. In earnings portfolio, $\mathrm{R}^{2}$ and adjusted $\mathrm{R}^{2}$ for the total sample are $11.7 \%$ and $11.5 \%$ respectively. Earnings response coefficient (ERC) is 2.751 and statistically has a significant positive relationship at $1 \%$ level. Also F statistic value (F-Value) for the total sample and each of the studied years is significant at $1 \%$ level. In contrast, in the loss portfolio, $\mathrm{R}^{2}$ and adjusted $\mathrm{R}^{2}$ for the total sample are respectively $0.5 \%$ and $-2.4 \%$. Earnings response coefficient in this portfolio is- 0.359 and statistically is not significant at conventional levels. Results indicate that portfolio of positive earnings (earnings), have a positive effect on the information content of earnings and statistically are significant. But the portfolio of negative earnings (loss) has a negative effect on the information content of earnings and statistically is not significant.

Part B shows simple regression results of operating cash flows (model 2) as a OCF positive portfolio (input operating cash flows) and OCF negative portfolio (output operating cash flow). In OCF positive portfolio, $\mathrm{R}^{2}$ and adjusted $\mathrm{R}^{2}$ for the total sample are $4.5 \%$ and $4.2 \%$ respectively. OCF response coefficient is 1.517 , and statistically has a significant positive relationship. In contrast, in OCF negative portfolio, $\mathrm{R}^{2}$ and adjusted $\mathrm{R}^{2}$ for the total sample are respectively $0.3 \%$ and $-2.1 \%$. OCF response coefficient in this portfolio is -0.166 and statistically is not significant at conventional 
levels. The results indicate that earnings have positive effect on the OCF value relationship and statistically are significant. But loss has negative effect on the OCF value relationship and statistically is not significant.

In general, earnings response coefficients and OCF for the loss are not statistically significant while earnings response coefficients and OCF for earnings are statistically significant. Remarkably, the results of this section are consistent with Daraghma's research results (2010).

Table 6. Results of loss affect test on the information content of earnings and operating cash flows

Part A: loss affect on the information content of earnings: $R_{i t}=\beta_{0}+\beta_{1} E_{i t}$

\begin{tabular}{|c|c|c|c|c|c|c|c|c|c|c|}
\hline \multicolumn{6}{|c|}{ portfolio of positive earnings (earnings) } & \multicolumn{5}{|c|}{ portfolio of negative earnings (loss) } \\
\hline $\begin{array}{l}\text { Yea } \\
\mathbf{r}\end{array}$ & $\beta_{0}$ & $\beta_{1}$ & F-Value & $\mathbf{R}^{2}$ & Adj. $\mathbf{R}^{2}$ & $\boldsymbol{\beta}_{0}$ & $\boldsymbol{\beta}_{1}$ & F-Value & $\mathbf{R}^{2}$ & Adj. $\mathbf{R}^{2}$ \\
\hline \multirow{2}{*}{2006} & $-0.341 *$ & $3.890 * *$ & $29.798 * *$ & 0.284 & 0.275 & -0.229 & -0.357 & 0.013 & 0.003 & -0.197 \\
\hline & -2.233 & 5.459 & & & & -1.309 & -0.003 & & & \\
\hline \multirow{2}{*}{2007} & $-0.180^{*}$ & $1.570 * *$ & $10.874 * *$ & 0.131 & 0.119 & -0.431 & -1.119 & 0.119 & 0.029 & -0.214 \\
\hline & -2.255 & 3.298 & & & & -2.009 & -0.345 & & & \\
\hline \multirow{2}{*}{2008} & $-0.206^{*}$ & $1.782 * *$ & $8.868 * *$ & 0.106 & 0.094 & $-0.465^{*}$ & -1.439 & 0.383 & 0.060 & -0.097 \\
\hline & -2.324 & 2.978 & & & & -2.567 & -0.619 & & & \\
\hline \multirow{2}{*}{2009} & -0.099 & $5.756^{* *}$ & $10.203 * *$ & 0.126 & 0.113 & 0.197 & 2.125 & 1.417 & 0.221 & 0.065 \\
\hline & -0.334 & 3.194 & & & & 0.924 & 1.190 & & & \\
\hline \multirow{2}{*}{2010} & -0.081 & $2.621 * *$ & $16.872 * *$ & 0.209 & 0.196 & $-0.258 *$ & 0.164 & 0.026 & 0.004 & -0.139 \\
\hline & -0.884 & 4.108 & & & & -2.889 & 0.162 & & & \\
\hline \multirow{2}{*}{$\begin{array}{l}\text { Polle } \\
\text { d }\end{array}$} & -0.133 & $2.751 * *$ & $48.920 * *$ & 0.117 & 0.115 & $-0.274 * *$ & -0.359 & 0.165 & 0.005 & -0.024 \\
\hline & -1.888 & 6.994 & & & & -3.667 & -0.406 & & & \\
\hline
\end{tabular}

Part B: loss affect on the information content of operating cash flows: $\mathrm{R}_{\mathrm{it}}=\theta_{0}+\theta_{1} \mathrm{OCF}_{\mathrm{it}}$

\begin{tabular}{|c|c|c|c|c|c|c|c|c|c|c|}
\hline \multicolumn{6}{|c|}{ OCF positive portfolio (input operating cash flows) } & \multicolumn{5}{|c|}{$\begin{array}{l}\text { OCF negative Portfolio (output operating cash } \\
\text { flows) }\end{array}$} \\
\hline $\begin{array}{l}\text { Yea } \\
\mathbf{r}\end{array}$ & $\boldsymbol{\theta}_{0}$ & $\theta_{1}$ & F-Value & $\mathbf{R}^{2}$ & Adj. $\mathbf{R}^{2}$ & $\theta_{0}$ & $\theta_{1}$ & F-Value & $\mathbf{R}^{2}$ & Adj. $\mathbf{R}^{2}$ \\
\hline \multirow{2}{*}{2006} & -0.135 & $2.806 * *$ & $10.137 * *$ & 0.115 & 0.104 & -0.277 & -5.565 & 1.120 & 0.272 & 0.029 \\
\hline & -0.807 & 3.184 & & & & -1.813 & -1.059 & & & \\
\hline \multirow{2}{*}{2007} & -0.053 & 0.631 & 2.732 & 0.038 & 0.024 & $-0.402 *$ & -1.413 & 1.118 & 0.123 & 0.013 \\
\hline & -0.720 & 1.653 & & & & -2.435 & -1.058 & & & \\
\hline \multirow{2}{*}{2008} & 0.048 & -0.347 & 0.404 & 0.005 & -0.008 & $-0.363^{*}$ & -0.458 & 0.430 & 0.097 & -0.129 \\
\hline & 0.509 & 0.527 & & & & -2.808 & -0.655 & & & \\
\hline \multirow{2}{*}{2009} & $0.475^{*}$ & 1.777 & 3.344 & 0.048 & 0.033 & 0.015 & $3.816^{*}$ & $6.952 *$ & 0.436 & 0.373 \\
\hline & 2.012 & 1.829 & & & & 0.161 & 2.637 & & & \\
\hline \multirow{2}{*}{2010} & 0.075 & 1.249 & 3.687 & 0.055 & 0.040 & $-0.249 *$ & -1.732 & 1.919 & 0.161 & 0.077 \\
\hline & 0.770 & 1.920 & & & & -2.814 & -1.385 & & & \\
\hline \multirow{2}{*}{$\begin{array}{l}\text { Polle } \\
\text { d }\end{array}$} & 0.035 & $1.517 * *$ & $17.023 * *$ & 0.045 & 0.042 & $-0.216^{* *}$ & -0.166 & 0.119 & 0.003 & -0.021 \\
\hline & 0.490 & 4.126 & & & & -4.346 & -0.345 & & & \\
\hline
\end{tabular}

** Correlation is significant at $1 \%$ level, * correlation is significant at $5 \%$ level. 


\subsubsection{Incremental Information Content of Earnings and Operating Cash Flows Test}

Table 7 shows the results of multiple linear regressions to the incremental information content of earnings and operating cash flows test. In this regression, independent variables are earnings and OCF. $\mathrm{R}^{2}$ and adjusted $\mathrm{R}^{2}$ for the total sample are $16.5 \%$ and $16.1 \%$ respectively. Earnings response coefficient (ERC) is 2.765 and statistically has a significant positive relationship at $1 \%$ level. But operating cash flow response coefficient (OCFRC) is 0.581 and statistically is not significant at conventional levels. This shows that earnings have incremental information content than $\mathrm{OCF}$, but the inverse is not true. With regard to the values of $\mathrm{R}^{2}$, adjusted $\mathrm{R}^{2}$ and Akaike information criteria (AIC), which are shown in Table 7, the results indicate that the incremental information content of earnings is more than the operating cash flows. Thus we can conclude that the fourth hypothesis of this research will be confirmed indicating that earnings have more incremental information content than operating cash flows related to explaining stock returns. The result is consistent with the research results of Haw et al.(2001) and Daraghma (2010) but is not consistent with the results of Charitou et al. (2000).

Table 7. Results of value relationship test for earnings and operating cash flows $-\mathrm{R}_{\mathrm{it}}=\gamma_{0}+\gamma_{1} \mathrm{E}_{\mathrm{it}}+\gamma_{2} \mathrm{OCF}_{\mathrm{it}}$

\begin{tabular}{lccccccc}
\hline Year & Constant $\left(\gamma_{0}\right)$ & $\gamma_{1}$ & $\gamma_{2}$ & F-Value & $\mathbf{R}^{2}$ & Adjusted $^{2}$ & AIC \\
\hline \multirow{2}{*}{$\mathbf{2 0 0 6}$} & $-0.277^{*}$ & $3.656^{* *}$ & -0.039 & $16.800^{* *}$ & 0.291 & 0.273 & -0.456 \\
& -1.996 & 4.411 & -0.041 & & & & \\
\hline \multirow{2}{*}{$\mathbf{2 0 0 7}$} & $-0.211^{* *}$ & $1.450^{* *}$ & 0.342 & $9.283^{* *}$ & 0.192 & 0.172 & -0.068 \\
& -3.223 & 3.231 & 1.072 & & & & \\
\hline \multirow{2}{*}{$\mathbf{2 0 0 8}$} & $-0.193^{*}$ & $2.338^{* *}$ & -0.581 & $9.012^{* *}$ & 0.182 & 0.162 & -1.304 \\
& -2.545 & 4.236 & -1.411 & & & & \\
\hline \multirow{2}{*}{$\mathbf{2 0 0 9}$} & 0.023 & $3.780^{*}$ & 1.267 & $6.980^{* *}$ & 0.153 & 0.131 & -2.708 \\
& 0.105 & 2.552 & 1.431 & & & & \\
\hline \multirow{2}{*}{$\mathbf{2 0 1 0}$} & -0.107 & $2.278^{* *}$ & 0.615 & $16.233^{* *}$ & 0.308 & 0.289 & -0.227 \\
& -1.581 & 4.473 & 1.304 & & & & -1.069 \\
\hline \multirow{2}{*}{ Polled } & $-0.191^{* *}$ & $2.765^{* *}$ & 0.581 & $39.854^{* *}$ & 0.165 & 0.161 &
\end{tabular}

** Correlation is significant at $1 \%$ level, * correlation is significant at 5\% level. $\gamma_{0}$ : intercept, $\gamma_{1}$ : Earnings response coefficient and $\gamma_{2}$ : operating cash flow response coefficient

\section{Conclusion}

While the results from hypotheses were different in studied years, it could be due to the different conditions dominated on society in studied years. Therefore we cannot provide an accurate judgment about the presented results. But what generally obtained from investigating the results of this research is that decision makers still consider accounting earnings in contrast with cash flows as the most important accounting variable in the financial and investment decisions in stock exchange market and often have information content than others.

This study has been carried out in line with Daraghma's research (2010). Three objectives which the present study have followed in this study are as follows: (1) Investigation of relative information content of earnings and operating cash flows; (2) Testing the loss effect on the information content of earnings and operating cash flows; and (3) Investigating the incremental information content of earnings and operating cash flows. In addition, this study has used statistical techniques such as, adjusted $\mathrm{R}^{2}$, Akaike information criteria (AIC) and Vuong's test to select the best model to explain stock returns to investigate the above-said objectives.

The present study investigated relative and incremental information content of earnings and operating cash flows in a sample of 475 firm-years among the Iranian companies listed in Tehran Stock Exchange during the years 2006-2010.The results from hypothesis test indicate that, (1) Earnings have more relative information content than operating cash flows in explaining stock returns. Also, according to Akaike information criteria (AIC) and Z Vuong's statistic values, earnings model is preferable to operating cash flows model. (2) Earnings has a positive and significant effect on the information content of earnings and operating cash flows but loss has a negative and non-significant effect on the information content of earnings and operating cash flows. (3) Incremental information content of 
earnings is higher than operating cash flows in explaining stock returns. Also the results show that Iranian investors in the stock assessment process and financial decision making in the Iranian capital market rely on the earnings more than operating cash flows. Remarkably, the results obtained in this study are consistent with the results of conducted research by Daraghma (2010).

\section{References}

Akaike, H. (1974). A new look at the statistical model identification. IEEE Transactions on Automatic Control, 19(6), 716-723. http://dx.doi.org/10.1109/TAC.1974.1100705

Ali, A. (1994). The Incremental Information Content of Earnings, Working Capital from Operations and Cash Flows. Journal of Accounting Research, 32(1), 61-74. http://dx.doi.org/10.2307/2491387

Audit Organization, Setting Committee. (2007). Accounting and Auditing Principles and Regulations: Accounting Standards, No. 2. Tehran, $16^{\text {th }}$ edition, Audit Organization Publishers.

Biddle, G. C., Seow, G. S., \& Siegel, A. F. (1995). Relative versus Incremental Information Content. Contemporary Accounting research, 12(1), 1-23. http://dx.doi.org/10.1111/j.1911-3846.1995.tb00478.x

Bowen, R. M., Burgstahler, D., \& Daley, L. A. (1987). The Incremental Information Content of Accrual versus Cash Flows. The Accounting Review, 62(4), 723-747.

Charitou, A., Clubb, C., \& Andreou, A. (2000). The Value Relevance of Earnings and Cash Flows: Empirical Evidence for Japan. Journal of International Financial Management and Accounting, 11(1), 563-594. http://dx.doi.org/ 10.1111/1467-646X.00053

Cheng, C. S. A., Liu. C., \& Schaefer, T. F. (1996). Earnings Permanence and the Incremental Information Content of Cash Flows from Operations. Journal of Accounting Research, 34(1), 173-181. http://dx.doi.org/10.2307/2491338

Daraghma, Z. M. A. (2010). The Relative and Incremental Information Content of Earnings and Operating Cash Flows: Empirical Evidence from Middle East, the Case of Palestine. European Journal of Economics, Finance and Administrative Sciences, 22, 123-135.

Dechow, P. M. (1994). Accounting Earnings and Cash Flows as Measures of Firm Performance: The Role of Accounting Accruals. Journal of Accounting and Economics, 18, 3-42. http://dx.doi.org/10.1016/0165-4101(94)90016-7

Dechow, P. M., Lys, T., \& Sabino, J. S. (1998). Addressing Recognition Issues in Accounting: An Evaluation of Alternative Research Approaches. Sloan School of Management, Email: (sabino@mit.edu).

Foroghi, D., \& Mazaheri, E. (2009). The power of earnings and operating cash flows in explaining the realized intrinsic value of the shares of companies listed in Tehran Stock Exchange. Journal of Financial Accounting researches, $1(1 \& 2), 1-16$.

Habib, A. (2008). The Role of Accruals and Cash Flows in Explaining Security Returns: Evidence from New Zealand. Journal of International Accounting, Auditing and Taxation, 17, 51-66. http://dx.doi.org/10.1016/j.intaccaudtax.2008.01.003

Hadi, M. M. (2006). The Value-Relevance of Income Levels and Components Reported. International Research Journal of Finance and Economics, 4, 133-142.

Haw, I. N., Qi, D., \& Wu, W. (2001). The Nature of Information in Accruals and Cash Flows in an Emerging Capital Market: The Case of China. The International Journal of Accounting, 36, 391-406. http://dx.doi.org/10.1016/S0020-7063(01)00107-8

Tehrani, R., \& Faniasl, M. (2007). The relationship between cash from operations and accrual earnings with stock returns of companies listed in Tehran Stock Exchange. Financial Research, 9(24), 21-32.

Wilson, G. P. (1986). The Relative Information Content of Accruals and Cash Flows: Combined Evidence at the Earnings Announcement and Annual Report Release Date. Journal of Accounting Research, 24, 165- 200. http://dx.doi.org/10.2307/2490736

\section{Notes}

Note 1. www.irbourse.com 